\title{
THYROGLOBULIN MEASUREMENT IN NEEDLE ASPIRATION FOR DETECTION OF RECURRENCES AND NECK METASTASES IN PATIENTS WITH DIFFERENTIATED THYROID CARCINOMA: SIGNIFICANCE OF ANTI-TG ANTIBODIES
}

\author{
Ivan Blažeković ${ }^{1}$, Matija Romić ${ }^{1}$, Marija Bosak Butković, Ines Šiško Markoš1, \\ Vedrana Gladić Nenadić ${ }^{1}$, Valentina Vidranski ${ }^{1}$, Petra Petranović Ovčariček ${ }^{1}$, \\ Dražena Krilić ${ }^{1}$, Tea Varjačić ${ }^{1}$, Josip Staničić ${ }^{1}$, Roko Granić ${ }^{1}$, Marija Punda ${ }^{1}$, \\ Ivan Mihaljević ${ }^{3,4}$, Tomislav Jukić ${ }^{1,2}$ and Maja Franceschi ${ }^{1,3}$
}

${ }^{1}$ Department of Oncology and Nuclear medicine, Sestre milosrdnice University Hospital Center, Zagreb, Croatia; ${ }^{2}$ School of Medicine, University of Zagreb, Zagreb, Croatia;

${ }^{3}$ Faculty of Medicine, University of Osijek, Osijek, Croatia;

${ }^{4}$ Department for Nuclear Medicine and Radiation Protection, Osijek University Hospital Center, Croatia

\begin{abstract}
SUMMARY - The worldwide incidence of differentiated thyroid cancer (DTC) has increased in recent decades, likely due to frequent use of cervical ultrasonography (US) and US-guided fine needle aspiration biopsy (FNA)., US is performed during follow-up after thyroidectomy, and US-guided FNA with cytology is used if suspicious cervical lymph nodes (LN) or thyroid bed masses are detected. Knowing that serum anti-Tg antibodies (s $\mathrm{TgAb})$ affect the use of serum $\mathrm{Tg}(\mathrm{s} \mathrm{Tg})$ as a tumor marker, the aim of our study was to assess the usefulness of $\mathrm{Tg}$ determination in needle aspirates (FNA-Tg) in presence of sTgAb. This retrospective study included 149 patients with DTC and 159 aspirations of suspicious $\mathrm{LN}$ and thyroid bed masses. As expected, there was a negative correlation between $s T g$ and $\mathrm{s} T g A b$ levels $(\mathrm{p}<0.05)$, while FNA-Tg levels had a positive correlation with FNA$\mathrm{TgAb}$ levels $(\mathrm{p}<0.05)$. Furthermore, we found a positive correlation between $\mathrm{sTg}$ and FNA-Tg levels $(\mathrm{p}<0.05)$, but not between sTgAb and FNA-TgAb or sTgAb and FNA-Tg. In conclusion, these results show that FNA-Tg values were not affected by sTgAb and that FNA-Tg measurement were highly effective in detecting cervical DTC metastases. However, combined use with cytology is suggested for neck evaluation because cytology could reveal metastases from other tumor sites.

Key words: neck ultrasonography, differentiated thyroid carcinoma, fine needle aspiration (FNA), serum thyroglobulin (sTg), serum anti-Tg antibodies (sTg-Ab), thyroglobulin ( $T g)$ in FNA (FNA-Tg), FNA anti-Tg antibodies ( $F N A-T g A b)$
\end{abstract}

\section{Introduction}

The worldwide incidence of thyroid cancer has increased several times in recent decades (1). Croatia is

Corresponding author: Maja Franceschi MD PhD, professor, Department of Oncology and Nuclear Medicine, UHC Sestre milosrdnice, Vinogradska 29, Zagreb, Croatia

E-mail: maja.franceschi@gmail.com currently the third country in Europe due to an incidence rate of 15.9 per 100.000 in 2016, whereas mortality has steadily declined $(2,3)$. This change is most likely due to the increased use of cervical ultrasonography (US) and US-guided fine needle aspiration biopsy (FNA). Patients with differentiated thyroid cancer (DTC) have a good prognosis, but since the implementation of a long-term follow-up monitoring scheme 
it has become clear that up to a third of patients present with persistent disease or recurrences (4). Recent studies demonstrated that patients with DTC have the highest incidence of local recurrences within the first 5 years (5). The risk of recurrences ranges from $2 \%$ to $14 \%$, in case of excellent response to therapy, while an incomplete response to initial therapy (suppressed $\mathrm{Tg}$ $>1 \mathrm{ng} / \mathrm{mL}$, stimulated $\mathrm{Tg}>10 \mathrm{ng} / \mathrm{mL}$, rising $\mathrm{Tg}$ values, or structural disease identification within the first 2 years of follow-up) increases the likelihood of persistent structural disease or recurrence from $13 \%$ to $79 \%$ in high-risk patients (6). Therefore, the risk of recurrence is associated with initial risk stratification based on clinico-pathologic features, but the estimated recurrence risk needs to be continually modified during follow-up, since it can change in response to therapy (6-8). Locoregional metastases are most often located in the cervical lymph nodes (LN) (60-75\%), and in the thyroid bed (20\%), with a diameter frequently under 1 $\mathrm{cm}(29-50 \%)(9,10)$. Follow-up of these patients after total thyroidectomy and radioiodine ablation of the thyroid remnant is mostly based on cervical US, serum thyroglobulin ( $\mathrm{s} \mathrm{Tg}$ ) measurement, and thyroptropin (TSH) measurement. Additional methods include SPECT/CT, bone scintigraphy, chest X-ray, CT, MR, or PET-CT, which should be used when necessary.

Cervical US is considered to be the best modality for the early detection of locoregional recurrences and thyroid bed recurrences of DTC in patients after thyroidectomy (11-13). The majority of recurrences are rarely palpable but are detected by US in $94-96 \%$ of cases (9). US-guided FNA with cytology is performed when suspicious cervical masses are detected. Tg measurement in fine needle aspirates was introduced in 1992 (14). US-guided FNA with cytology should be performed simultaneously with the measurement of $\mathrm{Tg}$ in needle aspirates (FNA-Tg) of suspicious nodes to confirm malignancy (11,15-17). Published data suggested that cytology alone was indicative of malignancy in $84.8 \%$, whereas cytology together with FNA$\mathrm{Tg}$ measurement was accurate in $95.6 \%$ patients (9). US characteristics of a suspicious mass in the thyroid bed include hypoechogenicity, microcalcifications, cystic changes, irregular borders, and increased intranodal vascularity. Sonographic features essential in evaluation of metastatic LN include loss of the fatty hilus, a rounded rather than oval shape, hypoechogenicity, cystic change, calcifications, and peripheral vascularity.
With regard to location location, malignant $\mathrm{LN}$ are much more likely to occur in levels VI, IV, and III than in level II. Cervical US can detect metastases as small as $2-3 \mathrm{~mm}$, but benefits of early discovery have not been demonstrated (8). Small (short axis $<5-7 \mathrm{~mm}$ ) cervical LNs in the lateral neck can remain stable during long periods of time and should just be regularly followed with serial US. That being said, it has been proposed to perform US guided FNA and Tg measurement for suspicious $\mathrm{LNs}>5-7 \mathrm{~mm}$ in its smallest diameter and thyroid bed lesions $\geq 10 \mathrm{~mm}(8,11$.)

Measurement of sTg is a sensitive and specific tumor marker for follow-up of patients with DTC after surgical removal of the thyroid gland and ablation of the remnant tissue $(18,19)$, with high degree of sensitivity and specificity in detecting recurrent disease and LN metastases. Immunochemistry assays are used to measure $\mathrm{sTg}$ in most laboratories. These assays are prone to interference from serum $\mathrm{Tg}$ autoantibodies (sTgAb), which are present in about $25 \%$ of patients and can falsely lower sTg values (20). The Level of interference can be dependent on the methodology used for analyzing $\mathrm{Tg}$ and $\mathrm{TgAb}$, with newer immunoassay techniques being less prone to false negative results. Regardless, $\mathrm{TgAb}$ should be always quantitatively assessed with measurement of sTg (21). Confirmed interference of sTgAb on sTg has raised potential concerns about using FNA-Tg result,s in presence of sTgAb. In 2013 Boi et al. (22) presented results showing no significant correlation between $\mathrm{sTgAb}$ and FNA-Tg values. In comparison, Jeon et al. (23), stated that FNA-Tg measurement was reliable in the diagnosis of neck metastases in PTC, even in cases with positive sTgAb, but high sTgAb levels could interfere with FNA-Tg measurements resulting in falsely low FNA-Tg levels.

The aim of our study was to assess the usefulness of FNA-Tg in the presence of sTgAb, while considering the possibility of $\mathrm{LN}$ contamination by sTgAb and alternatively active $\mathrm{LN} \mathrm{TgAb}$ synthesis.

\section{Methods}

This retrospective study included 149 patients (101 women and 48 men) with DTC, with ages ranging from 12 to 86 years. All subjects were Caucasians of Croatian origin. The medical records of patients were obtained from 2014 to 2016 at the Sestre milosrdnice 
Clinical Hospital Centre (Zagreb, Croatia) and reviewed retrospectively. All patients had received total thyroidectomy. Thyroxin therapy had been administered to patients after I-131 therapy. Patients were followed up by cervical US, sTg, and sTgAb determination and I-131 scintigraphy when necessary. When necessary, chest X-ray, bone scintigraphy, CT, MR, or PET-CT were performed. All procedures were in accordance with good clinical practice and with the Helsinki Declaration of 1975, as revised in 1983.

\section{Clinical measurements}

Cervical US was performed with "Xario" Toshiba using a linear 7-12 $\mathrm{MHz}$ probe and small convex 7 $\mathrm{MHz}$ probe for the evaluation of the upper mediastinum and for US-guided FNA. US of the thyroid bed and entire neck, including lateral cervical compartments and upper mediastinum, was performed. Color flow and power Doppler examination was included. US characterization of a suspicious mass in the thyroid bed included assessment of hypoechogenicity, microcalcifications, cystic changes, and increased intranodal vascularity. US features suggestive of metastatic LN included loss of the fatty hilus, a rounded rather than oval shape, hypoechogenicity, cystic change, calcifications, and peripheral vascularity. The location of the LN was also useful for decision-making. Malignant LN were much more likely to occur in levels VI, IV, and III than in level II.

US-guided FNA with cytology and FNA-Tg was obtained from US-suspicious neck masses. A 23-24 --gauge needle with parallel approach was used for US-guided FNA. US guidance and free hand technique was employed. A specimen for cytology was obtained by applying suction. The cytological specimen was prepared by making a slide smear and stained with May-Grünwald-Giemsa. The FNA cytology results were categorized as nonmalignant (reactive LN, some other benign disease), malignant cytology (metastatic DTC), or inadequate (cystic fluid, not enough cells for analysis). After smear preparation, the same needle and syringe were rinsed with $0.5 \mathrm{~mL}$ MultiAssay Diluent (Roche) to assess $\mathrm{Tg}$ in samples. This procedure does not require additional FNA. Tg was measured in washout fluid (FNA-Tg). When the aspiration samples were serous fluid, $\mathrm{Tg}$ was measured in the serous fluid without adding diluent. All smears were examined by the same cytologist.
Serum $\mathrm{Tg}$ was determined using the Cobas e411 (Roche Diagnostics, Mannheim, Germany) automated immunochemistry analyzer using ElectroChemiLuminescence (ECL) technology with an analytical sensitivity threshold of $0.04 \mathrm{ng} / \mathrm{mL}$ and a functional sensitivity threshold of $0.1 \mathrm{ng} / \mathrm{mL}$. Immunoassay was calibrated against the CRM-457 international standard. Tg in all aspirates (FNA-Tg) was measured with the same assay. $\mathrm{Tg}$ measurement in needle washout or cystic samples was performed using the same method as for sTg. In all patients, $\mathrm{Tg}-\mathrm{Ab}$ was measured using the Cobas e411 (Roche Diagnostics, Mannheim, Germany) automated immunochemistry analyzer using ElectroChemiLuminescence (ECL) technology with the analytical sensitivity $<10 \mathrm{IU} / \mathrm{mL}$ and a functional sensitivity threshold of $40 \mathrm{IU} / \mathrm{mL}$; antibody positivity was defined as a $\mathrm{TgAb}$ value exceeding $115 \mathrm{IU} / \mathrm{mL}$.

Serum $\mathrm{Tg}, \mathrm{TgAb}$, and TSH were measured within a few weeks before the US-guided FNA procedure.

The suspected LNs or suspected cervical tissue were categorized as benign or malignant. Relevant diagnostic procedures for confirming or excluding diagnosis were histology results from subsequent surgical excisions or FNA cytology results and/or FNA-Tg results and long-term US follow-up without changes in size if the surgery was not performed. Positive diagnosis was established if there was histological confirmation of metastasis or clear US evidence of metastasis with malignant cytology and/or FNA-Tg results. Negative diagnosis was established for those LN or masses with negative histology, cytology, and/or FNATg results.

\section{Statistical analysis}

Clinical data was reported using descriptive statistics. The results, expressed as means $(\mathrm{x}) \pm$ standard deviation $(\mathrm{SD})$ or medians, were evaluated with Statistica 10 Software. The correlation of data was evaluated using Spearman's correlation coefficient. The differences in the frequencies were evaluated using the Chi-square test. The level of significance was set to a p-value less than 0.05 .

\section{Results}

\section{Descriptive statistics}

In total, 149 patients were included in this study, 101 (67.79\%) women and 48 (32.21\%) men. Their me- 


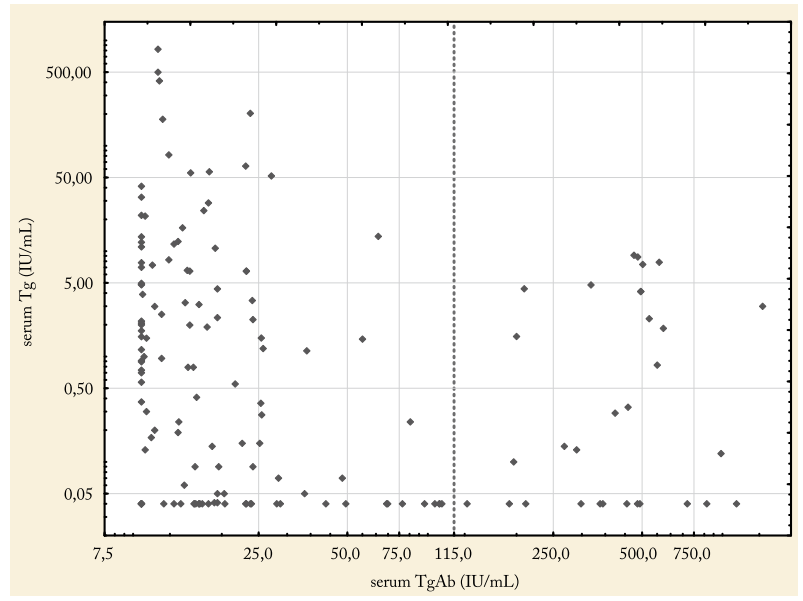

Figure 1. The patients were divided into two groups according to their $\operatorname{Tg} A b(I U / \mathrm{mL})$ levels.

dian age was 48 years (ranging from 12 to 86 years). Cervical US revealed 159 cervical LNs or masses in the thyroid bed suspected for malignancy. US-guided FNA with cytology was performed in all suspicious nodes. STg and sTgAb were determined in all $149 \mathrm{pa}-$ tients with US findings indicative for malignancy. FNA-Tg and $\mathrm{Tg}$ antibodies were determined in all washouts or cystic samples.

The patients were divided into two groups according to their $\mathrm{sTgAb}$ values (Figure 1). There were 31 (20.81\%) patients with positive sTgAb values and 118 (79.19\%) patients with negative sTgAb values.

Descriptive statistics of patients divided into two groups according to their sTgAb levels is presented in Table 1 . In 31 patients with positive sTgAb, cervical US revealed 34 suspicious nodes. Elevated FNA-Tg values were found in 11 patients and 13 samples, confirming locoregional malignancies. Among patients with positive FNA $\mathrm{Tg}$ values, there was a large discrepancy in FNA Tg Ab values. Namely, two patients had FNA TgAb values above 450 while the remaining 11 had values below 115 . In 10 of those samples with low FNA-TgAb, cytology was positive and was false negative in 1 sample. FNA-Tg values ranged from $1.26 \mathrm{ng} / \mathrm{mL}$ to $>500 \mathrm{ng} / \mathrm{mL}$. In the remaining two samples, FNA-Tg values were elevated to $>500 \mathrm{ng} /$ $\mathrm{mL}$, accompanied by high FNA-TgAb values, while cytology revealed malignancy in both samples without false negative results. Of those 31 patients with positive sTgAb, 20 had negative FNA-Tg with negative cytology findings for malignancy in 19 of those patients and nondiagnostic in one.
From a total of 118 patients with negative $s \mathrm{TgAb}$ and 125 nodes suspected for malignancy, 33 samples from 32 patients had elevated FNA-Tg values ranging from 1.62 to $>500 \mathrm{ng} / \mathrm{mL}$. In 19 of those, FNA-Tg positive cytology findings were positive for malignancy, 3 were suspicious for malignancy, 7 samples were negative for malignancy, and 4 samples were not suitable for diagnostics.

In total, 46 samples were positive for locoregional metastases of thyroid cancer or thyroid bed recurrences. Out of 46 samples with elevated FNA-Tg values, 34 had cytology findings positive or suspicious for thyroid malignancy, while 12 were negative on cytology for DTC. From those 12, 7 were in fact residual thyroid tissue and 5 were false negative. Cytology was positive for metastases of mucinous adenocarcinoma in one patient with undetectable FNA-Tg.

Table 1. Descriptive statistics

\begin{tabular}{|l|l|l|}
\hline & $\begin{array}{l}\text { sTgAb } \\
\text { positive }\end{array}$ & $\begin{array}{l}\text { sTgAb } \\
\text { negative }\end{array}$ \\
\hline Patients/suspicious nodes & $31 / 34$ & $118 / 125$ \\
Age-median (years) & $43(26-86)$ & $51(12-85)$ \\
s-Tg-median (ng/mL) & 0.14 & 0.79 \\
FNA-Tg-median (ng/mL) & 0.04 & 0.07 \\
$\begin{array}{l}\text { FNA-TgAb-median } \\
\text { (IU/mL) }\end{array}$ & 24.78 & 22.97 \\
$\begin{array}{l}\text { FNA-Tg-positive } \\
\text { patients/nodes } \\
\text { Cytology (patients /nodes) }\end{array}$ & $11 / 13$ & $32 / 33$ \\
Positive & $10 / 13$ & $21 / 22$ \\
Negative & $20 / 20$ & $81 / 82$ \\
Nondiagnostic & $1 / 1$ & $17 / 17$ \\
Potentially malignant & 0 & $4 / 4$ \\
\hline
\end{tabular}

\section{Correlation statistics}

Our results revealed a significant inverse correlation of sTg levels with sTgAb levels (Spearman's rho=$0.275, \mathrm{p}<0.05$ ) (Figure 1). On the other hand, our results showed a significant positive correlation of FNA$\mathrm{Tg}$ values with FNA-TgAb levels (Spearman's rho= $0.514, \mathrm{p}<0,05)$ (Figure 2). FNA TgAb values are not a commonly measured value and there is no accepted cutoff value. But if we consider a cutoff value of 115 for serum $\mathrm{TgAb}$, then there is a significant difference in the distribution of FNA-Tg values (chi 44.13, $\mathrm{p}<0.0001)$ among the groups of patients with FNA- 


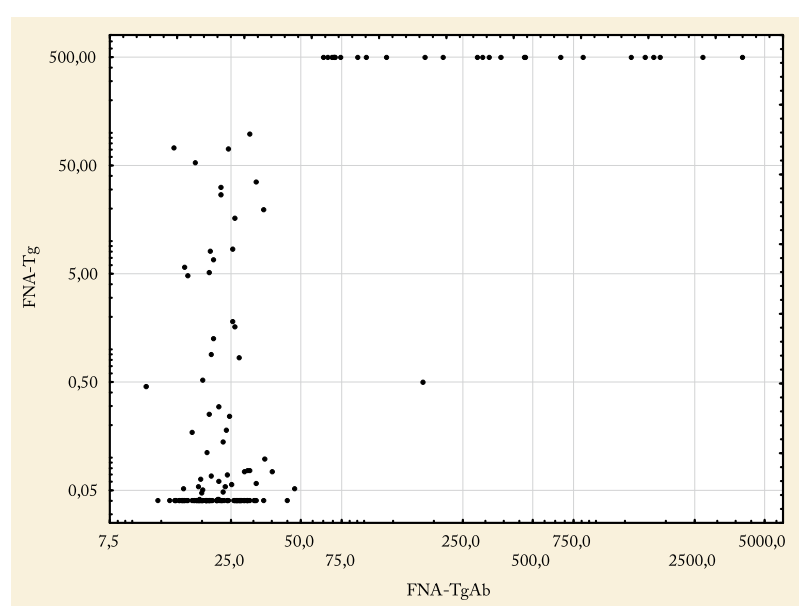

Figure 2. Correlation between FNA TgAb (IU/mL) and FNA Tg $(\mathrm{ng} / \mathrm{mL})$.

$\mathrm{TgAb}$ values of over and under 115 . In the group of patients with higher FNA-TgAb values, almost all had positive FNA-Tg values (17/18), while the proportion of patients with positive FNA-Tg was low among patients with low FNA-TgAb values (29/141).

Furthermore, there was also a significant positive correlation between sTg and FNA-Tg levels (Spearman's rho $=0.277, \mathrm{p}<0.05)$. The majority $(63.64 \%)$ of patients with FNA-Tg-positive values had also positive $\mathrm{s}-\mathrm{Tg}$ values and vice versa $(\mathrm{Chi} 8.87, \mathrm{p}<0.004)$.

On the other hand, our results have shown that there was no correlation between sTgAb and FNATgAb (Spearman's rho=0.118, $\mathrm{p}>0.05$ ), or between sTgAb and FNA-Tg (Spearman's rho=-0.013, p>0.05).

\section{Discussion}

Long-term follow-up of patients with DTC after total thyroidectomy should include appropriate methods for detecting possible recurrences. Patients with higher risk of recurrence should undergo follow-up examinations more frequently than the patients unlikely to develop relapse of disease. Measurement of sTg, cervical US, and occasionally whole-body scintigraphy are commonly used in the detection of metastases in patients with DTC $(8,24)$.

The measurement of sTg levels is an important modality included in follow-up of patients after a total thyroidectomy for DTC and radioiodine ablation of the remnant tissue $(18,25)$. sTg has a high degree of sensitivity and specificity for the detection of a recur- rent disease. The highest sensitivity is achieved following thyroid hormone withdrawal or stimulation using recombinant TSH (20). It is known that 1 gram of neoplastic tissue will increase $\mathrm{sTg}$ values by approximately $1 \mu \mathrm{g} / \mathrm{L}$ during levothyroxine treatment and by 2-10 $\mu \mathrm{g} / \mathrm{L}$ following TSH stimulation $(26,27)$. Patients considered disease free should have $\mathrm{sTg}<0.2 \mathrm{ng} /$ $\mathrm{mL}$ while on thyroid hormone therapy or $\mathrm{s} \mathrm{Tg}<1 \mathrm{ng} /$ $\mathrm{mL}$ after TSH stimulation (8). However, sTg measurement obtained during thyroid hormone suppression of TSH, and less commonly during TSH stimulation, may fail to detect patients with a relatively small amount of tumor tissue which are usually related to locoregional metastases $(12,28)$. Another drawback of this method is that $\mathrm{sTg}$ assays are prone to interference with sTgAb, which are present in about $25 \%$ of patients and falsely lower sTg values $(20,21)$. Our results also demonstrated a negative correlation between sTg and sTgAb values, although our automatic immunoassay method is more advanced than those cited, with less possible interference in $\mathrm{sTg}$ and $\mathrm{s} \mathrm{TgAb}$ detection.

Cervical US is a sensitive, but not specific tool for detection of locoregional recurrences $(29,30)$. USguided FNA with cytology of suspicious nodes is performed to confirm malignancy. However, FNA samples potentially have low cellularity that is lacking characteristic cytological features of thyroid cancer (31). Additionally, cystic changes in metastatic LN may be another diagnostic pitfall in FNA cytology. Determination of $\mathrm{Tg}$ in samples was introduced to overcome these disadvantages (14). A number of studies showed that FNA-Tg improves the sensitivity of cytology for the identifications of metastatic LN and thyroid bed recurrences $(9,11,16,21,23,32-35)$. Measurement of FNA-Tg enhances the sensitivity of cytology in up to $20 \%$ of aspirates $(33,36)$. Furthermore, it is important to point out the fact that the neck region is involved in a variety of extrathyroidal malignancies and that metastases of other cancer can potentially be detected by cytology in this region. That being said, we found that one patient suspected of DTC with undetectable FNA-Tg had a cytology result positive for metastases of mucinous adenocarcinoma. Most of the studies reported that diagnostic accuracy of FNA-Tg in the detection of neck malignancies is highly reliable even in cases with negative stimulated serum $\operatorname{Tg}(20,32,37)$. Furthermore, there is the ques- 
tion of FNA-Tg cutoff which varies between studies. The most used cutoff values are: FNA-Tg $<1 \mathrm{ng} / \mathrm{mL}$ suggests a benign nodule, while values of $\mathrm{Tg}>10 \mathrm{ng} /$ $\mathrm{mL}$ suggest presence of malignancy. When FNA-Tg measures are between $1 \mathrm{ng} / \mathrm{mL}$ and $10 \mathrm{ng} / \mathrm{mL}$, results should be compared with serum $\mathrm{Tg}$ (11). A more recent study suggested a value of $1.0 \mathrm{ng} / \mathrm{mL}$ FNA-Tg as a cutoff for diagnosing metastasis of papillary cancer $(15,38)$, which we also used in this study. Borel et al. described that low FNA Tg values below $10 \mathrm{ng} / \mathrm{FNA}$ can indicate DTC metastasis without a correlation to serum $\mathrm{Tg}$, even when expressed as total Tg left in needle after aspiration and not as concentration after washout. On the other hand, our results showed a significant positive correlation between sTg and FNATg levels.

While it is known that serum $\mathrm{TgAb}$ interferes with serum $\mathrm{Tg}$ measurement, producing underestimation of $\mathrm{Tg}$ concentration, some previous studies have shown that FNA-Tg measurement is valid in patients with circulating serum $\mathrm{Tg}-\mathrm{Ab}(9,16,20,32,34,37,39)$. A possible explanation was that intracellular $\mathrm{Tg}$ was not exposed to circulating sTgAb, but these results have not been confirmed in all studies (16). Jeon et al. reported in 2013 that LN metastases presented with lower FNA-Tg values in patientswho were sTgAb positive than in patients without sTgAb, suggesting that high sTgAb levels could interfere with FNA-Tg measurements and thereby result in falsely low FNA$\mathrm{Tg}$ levels (23). In comparison, in his more recent study Jeon described that preoperative FNA-Tg levels were not related to TSH or sTgAb (40). Furthermore, a study by Jo et al. suggested lower diagnostic accuracy of FNA-Tg in patients with positive sTgAb, but just in preoperative cases (41), while Shin et al. reported a possible effect of sTgAb on FNA-Tg cutoff values (42). On the other hand, Duval et al. reported no difference between FNA-Tg cutoff values in relation to sTgAb (43). It is very important to mention that these studies did not perform FNA-TgAb measurements as we have in our study. FNA-TgAb measurement is not a routinely used method, and it is important to emphasize that cut-off values for FNA-TgAb have not been determined. The question is what we can classify as a positive FNA-TgAb value. If we hypothetically take the same cutoff as for the $115 \mathrm{Iu} / \mathrm{mL}$ serum sTgAb, our results show a strong correlation of FNA-Tg values with FNA-TgAb levels as confirmed by Spearman correlation analysis, but further research is needed to set the actual cutoff for FNA-TgAb. In addition to these results, we demonstrated no statistically significant direct correlation between serum $\mathrm{TgAb}$ and FNA-Tg.

Our assumption that serum $\mathrm{TgAb}$ affects FNA-Tg implies that serum $\mathrm{TgAb}$ can affect FNA-TgAb. Alternatively, there is a possibility of metastatic $\mathrm{LN}$ active $\mathrm{TgAb}$ synthesis as proposed in 1984 (44). In this study, we demonstrated that there was no correlation between serum $\mathrm{TgAb}$ and FNA-TgAb values. Based on these results, we concluded that there can be no effect of $\mathrm{TgAb}$ on FNA-Tg except from potentially active metastatic $\mathrm{LN} \mathrm{TgAb}$ synthesis. In that regard, we demonstrated a positive correlation between FNA$\mathrm{TgAb}$ and FNA-Tg in both serum $\mathrm{TgAb}$ positive and negative patients, thus excluding the negative effect of FNA-TgAb on FNA-Tg values by active FNA-TgAb synthesis in LN.

The limitations of statistical analysis consisted in significantly elevated values of $\mathrm{Tg}$ in certain samples because no further sample dilution was performed. High FNA-Tg values over $2000 \mathrm{ng} / \mathrm{mL}$ can lead to false-elevated FNA-TgAb $(39,45)$. The limitation of our study design was that we did not have enough histological data for further comparison with cytology and FNA-Tg results. The reason for this was that our patients with smaller locoregional metastases were not sent for surgical removal until significant enlargement, which rarely occurred. When confirmation of malignancy was achieved by US-guided FNA with cytology and/or measurement of FNA-Tg, the preferred initial treatment was surgical removal of primary tumor and locoregional metastases $(46,47)$. While the resection of large, clinically apparent recurrences and locoregional metastases often provides a clinical benefit, it is uncertain whether the resection of small locoregional recurrence has any meaningful clinical impact. Small cervical LN metastases and thyroid bed recurrences can remain stable for longer periods of time and their significance is unclear $(8,10,28)$.

Combined use of US and US-guided FNA with cytology and FNA-Tg measurement are indicated for neck evaluation because of enhanced sensitivity for DTC, while metastases from other tumors could also be revealed by cytology findings. US-guided FNA performed to obtain both cytology samples and Tg determination is considered the best available technique for 
the early diagnosis of locoregional metastases. Our study indicates that determination of elevated $\mathrm{Tg} \mathrm{lev-}$ els in fine needle samples is effective in detection of cervical $\mathrm{LN}$ metastases and/or recurrences even in cases were cytology is nondiagnostic or negative and regardless of positive sTgAb.

\section{Acknowledgments}

None to declare.

\section{References}

1. La Vecchia C, Malvezzi M, Bosetti C, Garavello W, Bertuccio P, Levi F, et al. Thyroid cancer mortality and incidence: a global overview. Int J Cancer. 2015;136:2187-95. https://doi: 10.1002/ ijc. 29251

2. Croatian Institute for Public Health, Croatian National Cancer Registry. Cancer incidence in Croatia 2016, Bulletin 41, Zagreb, 2019.

3. Cancer Today [Internet]. Lyon: IARC; [cited 2020 Feb 23]. Available from: http:// gco.iarc.fr/today/home

4. Mazzaferri EL, Jhiang SM. Long-term impact of initial surgical and medical therapy on papillary and follicular thyroid cancer. Am J Med. 1994;97(5):418-28. Erratum in: Am J Med 1995;98(2):215. https://doi: 10.1016/0002-9343(94)90321-2

5. Mazzaferri EL, Kloos RT. Clinical review 128: Current approaches to primary therapy for papillary and follicular thyroid cancer. J Clin Endocrinol Metab. 2001;86(4):1447-63. https:// doi: 10.1210/jcem.86.4.7407

6. Tuttle RM, Tala H, Shah J, Leboeuf R, Ghossein R, Gonen M, et al. Estimating risk of recurrence in differentiated thyroid cancer after total thyroidectomy and radioactive iodine remnant ablation: using response to therapy variables to modify the initial risk estimates predicted by the new American Thyroid Association staging system. Thyroid. 2010;20(12):1341-9. https://doi: 10.1089/thy.2010.0178

7. Prpić M, Franceschi M, Romić M, Jukić T, Kusić Z. Thyroglobulin as a Tumor Marker in Differentiated Thyroid Cancer - Clinical Considerations. Acta Clin Croat. 2018;57(3): 518-527. https://doi:10.20471/acc.2018.57.03.16

8. Haugen BR, Alexander EK, Bible KC, Doherty GM, Mandel SJ, Nikiforov YE, et al. 2015 American Thyroid Association Management Guidelines for Adult Patients with Thyroid Nodules and Differentiated Thyroid Cancer: The American Thyroid Association Guidelines Task Force on Thyroid Nodules and Differentiated Thyroid Cancer. Thyroid. 2016;26(1):1-133. https://doi:10.1089/thy.2015.0020

9. Frasoldati A, Pesenti M, Gallo M, Caroggio A, Salvo D, Valcavi R.. Diagnosis of neck recurrences in patients with differentiated thyroid carcinoma. Cancer. 2003; 97:90-96. https://doi: 10.1002/cncr.11031
10. Torlontano M, Attard M, Crocetti U, Tumino S, Bruno R, Costante $\mathrm{G}$, et al. Follow-up of low risk patients with papillary thyroid cancer: role of neck ultrasonography in detecting lymph node metastases. J Clin Endocrinol Metab. 2004;89(7):3402-7. https://doi: 10.1210/jc.2003-031521

11. Leenhardt L, Erdogan MF, Hegedus L, Mandel SJ, Paschke R, Rago T, et al. 2013 European thyroid association guidelines for cervical ultrasound scan and ultrasound-guided techniques in the postoperative management of patients with thyroid cancer. Eur Thyroid J. 2013;2(3):147-59. https://doi: 10.1159/000 354537

12. Schlumberger M, Pacini F, Wiersinga WM, Toft A, Smit JW, Sanchez Franco F, et al. Follow-up and management of differentiated thyroid carcinoma: a European perspective and clinical practice. Eur J Endocrinol. 2004;151:539-548. https://doi: 10.1530/eje.0.1510539

13. Franceschi M, Kusić Z, Franceschi D, Lukinac L, Roncević S. Thyroglobulin Determination, Neck Ultrasonography and Iodine-131 Whole Body Scintigraphy in Differentiated Thyroid Carcinoma. J Nucl Med. 1996; 37:446-451

14. Pacini F, Fugazzola L, Lippi F, Ceccarelli C, Centoni R, Miccoli $\mathrm{P}$, et al. Detection of thyroglobulin in fine needle aspirates of nonthyroidal neck masses: a clue to the diagnosis of metastatic differentiated thyroid cancer. J Clin Endocrinol Metab. 1992;74(6):1401-4. https://doi: 10.1210/jcem.74.6.1592886

15. Moon JH, Kim Yi, Lim JA, Choi HS, Cho SW, Kim KW, et al. Thyroglobulin in washout fluid from lymph node fine-needle aspiration biopsy in papillary thyroid cancer: large scale validation of the cut-off value to determine malignancy and evaluation of discrepancy results. J Clin Endocrinol Metab. 2013; 98:1061-1068. https://doi: 10.1210/jc.2012-3291

16. Baskin HJ. Detection of recurrent papillary thyroid carcinoma by thyroglobulin assessment in the needle washout after fineneedle aspiration of suspicious lymph nodes. Thyroid. 2004; 14:959-963. https://doi: 10.1089/thy.2004.14.959

17. Borel AL, Boizel R, Faure P, Barbe G, Boutonnat J, Sturm N, et al. Significance of low levels of thyroglobulin in fine needle aspirates from cervical lymph nodes of patients with a history of differentiated thyroid cancer. Eur J Endocrinol. 2008;158 (5):691-8. https://doi: 10.1530/EJE-07-0749

18. Eustatia-Rutten CF, Smit JW, Romijn JA, van der Kleij-Corssmit EP, Pereira AM, Stokkel MP, et al. Diagnostic value of serum thyroglobulin measurements in thefollow-up of differentiated thyroid carcinoma, a structured meta-analysis. Clin Endocrinol (Oxf). 2004 ;61(1):61-74. https://doi: 10.1111/j.13652265.2004.02060.x

19. Pak K, Suh S, Hong H, Cheon GJ, Hahn SK, Kang KW, et al. Diagnostic values of thyroglobulin measurement in fine-needle aspiration of lymph nodes in patients with thyroid cancer. Endocrine. 2015;49(1):70-7. https://doi: 10.1007/s12020014-0410-z

20. Spencer CA, Bergoglio LM, Kazarosyan M, Fatemi S, LoPresti JS. Clinical impact $\mathrm{f}$ thyroglobulin $(\mathrm{Tg})$ and $\mathrm{Tg}$ autoantibody method differences on the management of atients with differ- 
entiated thyroid carcinomas. J Clin Endocrinol Metab. 2005; 90(10):5566-75. https://doi: 10.1210/jc.2005-0671

21. Spencer CA, Lopresti JS. Measuring thyroglobulin and thyroglobulin autoantibody in patients with differentiated thyroid cancer. Nat Clin Pract Endocrinol Metab. 2008r;4(4):223-33. https://doi: 10.1038/ncpendmet0757

22. Boi F, Minerba L, Lai ML, Marziani B, Figus B, Spanu F, et al. Both thyroid autoimmunity and increased serum TSH are independent risk factors for malignancy in patients with thyroid nodules. J Endocrinol Invest. 2013;36(5):313-20. https://doi: $10.3275 / 8579$

23. Jeon MJ, Park JW, Han JM, Yim JH, Song DE, Gong G, et al. Serum antithyroglobulin antibodies interfere with thyroglobulin detection in fine-needle aspirates of metastatic neck nodes in papillary thyroid carcinoma. J Clin Endocrinol Metab. 2013;98(1):153-60. https://doi: 10.1210/jc.2012-2369

24. Xu Y,Wu D, Wu W, Jiang J, Xi C, Ye N, et al. Diagnostic value of cytology, thyroglobulin, and combination of them in fineneedle aspiration of metastatic lymph nodes in patients with differentiated thyroid cancer: A systematic review and network meta-analysis. Medicine (Baltimore). 2019;98(45):e17859. https://doi: 10.1097/MD.0000000000017859

25. Grebe SKG. Diagnosis and management of thyroid carcinoma: a focus on serum thyroglobulin. Expert Rev Endocrinol Metab. 2009;4:25-43. https://doi: 10.1586/17446651.4.1.25

26. Spencer C, Fatemi S, Singer P, Nicoloff J, Lopresti J. Serum Basal thyroglobulin measured by a second-generation assay correlates with the recombinant human thyrotropin-stimulated thyroglobulin response in patients treated for differentiated thyroid cancer. Thyroid. 2010;20(6):587-95. https://doi: 10.1089/thy.2009.0338

27. Bachelot A, Cailleux AF, Klain M, Baudin E, Ricard M, Bellon $\mathrm{N}$, et al. Relationship between tumor burden and serum thyroglobulin level in patients with papillary and follicular thyroid carcinoma. Thyroid. 2002;12(8):707-11. https://doi:10.1089/ 105072502760258686

28. Robenshtok E, Fish S, Bach A, Domínguez JM, Shaha A, Tuttle RM. Suspicious cervical lymph nodes detected after thyroidectomy for papillary thyroid cancer usually remain stable over years in properly selected patients. J Clin Endocrinol Metab. 2012; 97(8):2706-13. https://doi: 10.1210/jc.2012-1553

29. Torlontano M, Crocetti U, Augello G, D'Aloiso L, Bonfitto N, Varraso A, et al. Comparative evaluation of recombinant human thyrotropin-stimulated thyroglobulin levels, 131I wholebody scintigraphy, and neck ultrasonography in the follow-up of patients with papillary thyroid microcarcinoma who have not undergone radioiodine therapy. J Clin Endocrinol Metab. 2006;91(1):60-3. https://doi: 10.1210/jc.2005-1185

30. Białek EJ, Jakubowski W. Mistakes in ultrasound diagnosis of superficial lymph nodes. J Ultrason. 2017;17(68):59-65. https: //doi: 10.15557/JoU.2017.0008

31. Zhao L, Gong Y, Wang J, Dawlett M, Huo L, Caraway NP, et al. Ultrasound-guided fine-needle aspiration biopsy of thyroid bed lesions from patients with thyroidectomy for thyroid carci- nomas. Cancer Cytopathol. 2013;121(2):101-7. https://doi: 10.1002/cncy.21202

32. Boi F, Baghino G, Atzeni F, Lai ML, Faa G, Mariotti S. The diagnostic value for differentiated thyroid carcinoma metastases of thyroglobulin $(\mathrm{Tg})$ measurement in washout fluid from fine-needle aspiration biopsy of neck lymph nodes is maintained in the presence of circulating anti-Tg antibodies. J Clin Endocrinol Metab. 2006;91(4):1364-9. https://doi: 10.1210/ jc. 2005-1705

33. Cignarelli M,Ambrosi A, Marino A, Lamacchia O, Campo M, Picca G, et al. Diagnostic utility of thyroglobulin detection in fine-needle aspiration of cervical cystic metastatic lymph nodes from papillary thyroid cancer with negative cytology. Thyroid. 2003;13(12):1163-7.https://doi:10.1089/10507250360731578

34. Suh YJ, Son EJ, Moon HJ, Kim EK, Han KH, Kwak JY. Utility of thyroglobulin measurements in fine-needle aspirates of space occupying lesions in the thyroid bed after thyroid cancer operations. Thyroid. 2013;23(3):280-8. https://doi: 10.1089/ thy.2011.0303

35. Kim MJ, Kim EK, Kim BM, Kwak JY, Lee EJ, Park CS, et al. Thyroglobulin measurement in fine-needle aspirate washouts: the criteria for neck node dissection for patients with thyroid cancer. Clin Endocrinol (Oxf). 2009;70(1):145-51. https://doi: 10.1111/j.1365-2265.2008.03297.x

36. Cunha N, Rodrigues F, Curado F, Ilhéu O, Cruz C, Naidenov $\mathrm{P}$, et al. Thyroglobulin detection in fine-needle aspirates of cervical lymph nodes: a technique for the diagnosis of metastatic differentiated thyroid cancer. Eur J Endocrinol. 2007;157(1): 101-7. https://doi: 10.1530/EJE-07-0088

37. Latrofa F, Ricci D, Montanelli L, Rocchi R, Piaggi P, Sisti E, et al. Thyroglobulin autoantibodies in patients with papillary thyroid carcinoma: comparison of different assays and evaluation of causes of discrepancies. J Clin Endocrinol Metab. 2012; 97(11):3974-82. https://doi: 10.1210/jc.2012-2406

38. Grani G, Fumarola A. Thyroglobulin in lymph node fine-needle aspiration washout: a systematic review and meta-analysis of diagnostic accuracy. J Clin Endocrinol Metab. 2014;99(6): 1970-82. https://doi: 10.1210/jc.2014-1098

39. Martins-Costa MC, Maciel RMB, Kasamatsu TS, Nakabashi $\mathrm{CCD}$, Camacho CP, Crispim F, et al. Clinical impact of thyroglobulin $(\mathrm{Tg})$ and $\mathrm{Tg}$ autoantibody $(\mathrm{TgAb})$ measurements in needle washouts of neck lymph node biopsies in the management of patients with papillary thyroid carcinoma. Arch Endocrinol Metab. 2017;61(2):108-114. https://doi: 10.1590/23593997000000241

40. Jeon MJ, Kim WG, Jang EK, Choi YM, Lee YM, Sung TY, et al. Thyroglobulin level in fine-needle aspirates for preoperative diagnosis of cervical lymph node metastasis in patients with papillary thyroid carcinoma: two different cutoff values according to serum thyroglobulin level. Thyroid. 2015;25(4):410-6. https://doi: 10.1089/thy.2014.0544

41. Jo K, Kim MH, Lim Y, Jung SL, Bae JS, Jung CK, et al. Lowered cutoff of lymph node fine-needle aspiration thyroglobulin 
in thyroid cancer patients with serum anti-thyroglobulin antibody. Eur J Endocrinol. 2015;173(4):489-97. https://doi: 10.1530/EJE-15-0344

42. Shin HJ, Lee HS, Kim EK, Moon HJ, Lee JH, Kwak JY. A Study on Serum Antithyroglobulin Antibodies Interference in Thyroglobulin Measurement in Fine-Needle Aspiration for Diagnosing Lymph Node Metastasis in Postoperative Patients. PLoS One. 2015;10(6):e0131096. https://doi: 10.1371/journal.pone.0131096

43. Duval MADS, Zanella AB, Cristo AP, Faccin CS, Graudenz MS, Maia AL. Impact of Serum TSH and Anti-Thyroglobulin Antibody Levels on Lymph Node Fine-Needle Aspiration Thyroglobulin Measurements in Differentiated Thyroid Cancer Patients. Eur Thyroid J. 2017;6(6):292-297. https://doi: $10.1159 / 000479682$
44. Weetman AP, McGregor AM, Wheeler MH, Hall R. Extrathyroidal sites of autoantibody synthesis in Graves' disease. Clin Exp Immunol. 1984;56(2):330-6

45. Giovanella L, M Clark P, Chiovato L, Duntas L, Elisei R Feldt-Rasmussen U, et al. Thyroglobulin measurement using highly sensitive assays in patients with differentiated thyroid cancer: a clinical position paper. Eur J Endocrinol. 2014; 171:R33-R46. https://doi: 10.1530/EJE-14-0148

46. Prstačić R, Bumber B, Marjanović Kavangh M, Jurlina M, Ivković I, Prgomet D. Metastasis predictors for neck sublevel IIb in papillary thyroid carcinoma. Clin Otolaryngol. 2020 May 3. doi: 10.1111/coa.13562. [Epub ahead of print].

47. Kusić Z, Prgomet D. Karcinom štitne i doštitne žljezde. U: Prgomet D, ur. Tumori glave i vrata. Zagreb:Medicinska naklada; 2019. Str. 262-73.

Sažetak

\title{
ODREĐIVANJE VRIJEDNOSTI TIREOGLOBULINA U CITOLOŠKOM ASPIRATU U SVRHU OTKRIVANJA RECIDIVA I METASTAZA NA VRATU U BOLESNIKA S DIFERENCIRANIM KARCINOMOM ŠTITNJAČE: ZNAČAJ ANTI-TG PROTUTIJELA
}

\author{
I. Blažekovic, M. Romić, M. Bosak Butković, I. Šiško Markoš, V. Gladić Nenadić, V. Vidranski, \\ P. Petranović Ovǐariček, D. Krilic, T. Varjačic, J. Staničic, R. Granic, M. Punda, I. Mibaljevic, T. Jukić i M. Franceschi
}

Svjetska incidencija diferenciranog karcinoma štitnjače (DTC) u porastu je posljednjih desetljeća najvjerojatnije zbog povećane uporabe ultrazvuka (US) i US vođene aspiracijske biopsije tankom iglom (FNA). Nakon provedene tireoidektomije, onkološko praćenje uključuje US i US vođenu FNA i citološku analizu aspirata ukoliko se otkriju sumnjivi cervikalni limfni čvorovi (LN) ili tkivo u ležištu štitnjače. Kako je poznato da serumska protutijela na tireoglobulin (sTgAb) utječu na vrijednost serumskog $\mathrm{Tg}(\mathrm{s} \mathrm{Tg})$ kao tumorskog markera, cilj našeg istraživanja je procijeniti korisnost određivanja $\mathrm{Tg}$ u aspiratima suspektnih lezija (FNA-Tg) u prisutnosti sTgAb. Ova retrospektivna studija obuhvatila je 149 bolesnika s DTC-om i 159 uzoraka sumnjivih LN ili tkiva u ležištu štitnjače. Očekivano su razine sTg pokazale obrnutu korelaciju s razinom sTgAb ( $p<0,05)$, ali su vrijednosti FNA-Tg imale značajnu pozitivnu korelaciju s vrijednošću FNA-TgAb ( $<<0,05)$. Našim rezultatima smo pokazali pozitivnu korelaciju vrijednosti sTg i FNA-Tg $(\mathrm{p}<0,05)$, ali ne i korelaciju između sTgAb i FNA-TgAb, kao niti sTgAb i FNA-Tg. Zaključujemo da vrijednosti sTgAb ne utječu na FNA-Tg te da je određivanje FNA-Tg visoko učinkovita metoda dijagnostike regionalnih metastaza DTC. Međutim, preporučuje se kombinirana upotreba s citologijom za procjenu suspektnih čvorova vrata jer se citolologijom mogu istodobno otkriti metastaze i drugih tumora.

Ključne riječi: ultrazvuk vrata, diferencirani karcinom štitnjače, aspiracijska biopsija tankom iglom (FNA), serumski tireoglobulin (sTg), serumska anti-Tg protutijela (sTg-Ab), tireoglobulin $(T g)$ u aspiratu ( $F N A-T g)$, anti-Tg protutijela u aspiratu (FNA-TgAb) 